\section{Alessandra Bruschi'}

Cristiane Silvestre de Paula"

Isabel Altenfelder Santos Bordin'

\section{Lifetime prevalence and help seeking behavior in physical marital violence}

\begin{abstract}
OBJECTIVE: To estimate the lifetime prevalence of physical marital violence among women from a low-income urban community and to investigate help-seeking behavior among victims.
\end{abstract}

METHODS: This is the Brazilian pilot cross-sectional study for an international multicenter study conducted in 1999, and is based on a probabilistic cluster sample from the municipality of Embu, São Paulo State. We considered as eligible women aged 15 to 49 years, living with children under age 18 years, who had lived with a husband or partner in lifetime. Information was collected using standardized questionnaires $(n=86)$, administered by trained interviewers. We investigated three types of physical violence: severe (kicking, hitting with fist, beating, and/or use/ threat to use weapon), non-severe (slapping in the absence of severe violence), and any type (severe and/or non-severe and/or other physical aggressions spontaneously referred), as well as the type of help sought by the victim (from people or institutions). We calculated frequency and $95 \%$ confidence intervals for each type of violence.

RESULTS: Subjects reported slapping (32.6\%), hitting with fist (17.5\%), beating (15.2\%), use/threat to use weapon (13.9\%), and kicking (10.6\%). Prevalence of marital violence was high: $22.1 \%(13.3-30.9)$ for severe violence, $10.5 \%$ (4.0-17.0) for non-severe violence, and $33.7 \%$ (32.7-34.7) for any type of violence. Victims of severe violence were more likely to seek help from the police $(36.8 \%)$ or from traditional healers $(21.1 \%)$ than from health care facilities $(5.3 \%)$, despite the availability of these services in the area.

CONCLUSIONS: Physical marital violence is frequent and severe among the population studied, and help was sought preferentially from the police or traditional healers rather than from health care services.

KEYWORDS: Domestic violence. Spouse abuse. Battered women. Prevalence. Cross-sectional studies. Women's health services. Social support.
Departamento de Psiquiatria. Escola Paulista de Medicina. Universidade Federal de São Paulo. São Paulo, SP, Brasil

" Faculdade de Psicologia. Universidade Presbiteriana Mackenzie. São Paulo, SP, Brasil

\section{Correspondence:}

Isabel A. S. Bordin

Setor de Psiquiatria Social - Unifesp

Rua Botucatu, 572 Cj. 101

04023-061 São Paulo, SP, Brasil

E-mail: fbordin@dialdata.com.br 


\section{INTRODUCTION}

Violence against women is a serious problem, affecting families from different countries and social strata. ${ }^{10}$ Awareness of this issue increased in Brazil in the 1980 's, when such violence was widely debated by the feminist movement, leading to greater involvement of the population. During this decade, both Federal and State administrations created female councils aimed to address the problem of marital violence. In 1984, the United Nation's Convention on the Elimination of All Forms of Discrimination against Women (CEDAW) was ratified in Brazil. In the following year, police departments were created that specialized in crimes involving violence against women and that were composed only of female police officers. ${ }^{7}$ However, the prevalence of physical marital violence and the type of help sought by victims are still largely unknown, and deserve further investigation by population-based studies.

A review of the literature on population-based studies on the lifetime prevalence of physical marital violence showed that, in developed countries, ${ }^{4,11,12,14,15,18}$ prevalence ranges from $5.3 \%^{14}$ to $25 \%^{20}$ for any type of violence and from $7.1 \%{ }^{15}$ to $18 \%{ }^{12}$ for severe violence. The methods employed in each of these studies are very similar, with a predominance of crosssectional designs, sampling by random selection of telephone numbers, focus on women in reproductive age, and definitions of physical marital violence based on the Conflict Tactics Scale. ${ }^{16}$

In developing countries, population-based studies of lifetime physical marital violence have been conducted in Latin-America, ${ }^{6,20, *, * *}$ Asia, ${ }^{8,17}$ and Africa. ${ }^{9}$ In these studies, prevalence ranged from $19.1 \%$ to $47 \%$ for any type of violence and from $20 \%$ to $37.8 \%$ for severe violence. In most of these surveys, data was collected by means of personal interviews carried out by trained interviewers. However, more than half of these studies did not include clear definitions of the type of physical marital violence measured.

On the whole, the above listed population-based studies indicate that a high percentage of physically abused women do not seek any type of help. When they do, these women resort mostly to individuals (family and friends) and institutions (police, facilities specific for victims of domestic violence, and healthcare professionals).
Studies conducted in Brazil show that marital violence affects a large number of women. A nationwide study ${ }^{19}$ evaluated the role of women in the private and public realms using a sample of women stratified by age and by the country's five great Regions. The researchers interviewed a total of 2,502 women aged 15 years or older, living in the rural or urban areas of 187 municipalities of 24 states, who answered a structured questionnaire. The study reported $33 \%$ prevalence of any type of physical violence and $22 \%$ prevalence of aggression. However, the majority of data available for Brazil was obtained using samples of health care facility users, ${ }^{2,5,13}$ and thus did not generate information on the problem in the general population nor on the helpseeking patterns adopted by victims.

The aim of the present study was to estimate the lifetime prevalence of physical marital violence among women from a low-income urban community and to describe the help-seeking behavior among victims.

\section{METHODS}

The present study was the pilot stage of the Brazilian Study of Abuse in Family Environments (BrazilSAFE). It is part of a multicenter project called World Studies of Abuse in Family Environments (WorldSAFE), which is an international initiative involving researchers from Brazil, Chile, Egypt, Philippines, India, and United States. ${ }^{3}$ The present study was conducted in 1999 in the Jardim Santa Emília neighborhood, a lowincome area of the municipality of Embu, Southeastern Brazil. There were no slums in this neighborhood. The choice of municipality was due to the possibility of developing local interventions.

The study was based on a probabilistic cluster sample, in which all eligible households were identified. The random selection of the four clusters (geographical areas with maximal internal homogeneity and of similar size within census sectors) from Jardim Santa Emília was carried out by the Instituto Brasileiro de Geografia e Estatística (Brazilian Institute of Geography and Statistics - IBGE). This institute also elaborated maps for the selected street blocks. All households on these blocks were visited. The names and ages of each household member were recorded. Households were defined based on the opinion of household members. The mapping of the first two clusters resulted in 97 eligible households (initial sample). The third and fourth clusters were used as a source of eligible households for replacement of eventual

\footnotetext{
*Schraiber LB, Oliveira AFPL, França-Jr I, Diniz CSG, Portella AP, Ludermir AB, et al. Violência contra a mulher e saúde no Brasil. São Paulo: Departamento de Medicina Preventiva da Faculdade de Medicina da Universidade de São Paulo; 2002.

**Schraiber LB, Oliveira AFPL, França-Jr I, Diniz CSG, Portella AP, Ludermir AB, et al. Prevalência de violência física contra a mulher cometida por parceiros na cidade de São Paulo e Zona da Mata de Pernambuco e sua distribuição segundo características sociodemográficas [resumo]. Rev Bras Epidemiol. 2002;(Supl esp):36
} 
losses (refusals, changes of address, and more than tree absences to interviews at the neighborhood health facility, scheduled at times chosen by the subjects). The replacement of losses proceeded consecutively along the list of eligible households in the third and fourth clusters. Each loss from the initial sample was replaced by a single substitute household. In case the substitution led to a further loss, this loss was computed into the final sample $(\mathrm{N}=86$; losses $=11.3 \%)$. Eligible households included at least one woman aged $15-49$ years, with one or more children aged $<18$ years also living in the house, and who had lived with a husband or partner any time in life. When more than one eligible woman was present per household, only one was randomly selected.

After providing informed consent, women were interviewed individually at the health center by psychologists and social workers specializing in mental health. In order to facilitate the reporting of marital violence, all interviewers were female. Interviewers underwent a 32-hour training program with a member of the WorldSAFE study, aimed specifically at training interviewers to be non-judgemental in the administration of standardized questionnaires. The questions used for the identification of marital violence were derived from the Conflict Tactics Scale ${ }^{16}$ instrument. BrazilSAFE followed the WorldSAFE research protocol, which did not include the complete instrument in order not to excessively extend the interview, as marital violence was one among different themes addressed by the multicenter study.

"Any type of physical marital violence" included slapping, kicking, hitting with fist, beating, using or threatening to use weapon, and/or other types of physical aggression spontaneously mentioned by women. "Severe physical marital violence" included kicking, hitting with fist, beating, and/or using or threatening to use weapon. "Non-severe physical marital violence" was defined as slapping in the absence of severe violence. We identified the type of help sought by victims, including both persons and institutions.

At the end of the interview, the professionals gave emotional support to the victims and counseled them to seek specialized services.

\section{RESULTS}

The women in the sample were aged 20-49 years (mean; $\mathrm{SD}=34 ; 7.1$ ), $42 \%$ of women had never studied or had not completed the first grade of elementary school (median schooling=2 years), and $52.3 \%$ were not working for pay at the time of the interview. The great majority of women $(81.4 \%)$ had had only one husband/partner in life, and over one-half of them $(59.7 \%)$ had been married for over 10 years (Table 1).

Family sociodemographic profile showed that $56.9 \%$ of households were composed of three or four members (median=4). Families usually consisted of the woman, a husband, and two children, with one resident per room in the house (excluding bathrooms) in $60.5 \%$ of cases. More than one-half of women were living in the same house for over five years, and $66.3 \%$ of families owned the homes they lived in or were paying mortgages. When asked about who was the head of the household, $84 \%$ of women indicated the husband or partner. In households that did not in-

Table 1 - Sociodemographic characteristics of the sample of women (N=86). Embu, Southeastern Brazil, 1999.

\begin{tabular}{lr}
\hline Sociodemographic characteristics & $\mathrm{N}(\%)$ \\
\hline Age (years) & \\
$20-29$ & $26(30.2)$ \\
$30-39$ & $39(45.4)$ \\
$40-49$ & $21(24.4)$ \\
Schooling (last grade completed) & \\
$\quad$ Never studied or $1^{\text {st }}$ grade of elementary school incomplete & $37(43.0)$ \\
$\quad$ Completed any grade between $1^{\text {st }}$ and $7^{\text {th }}$ & $37(43.0)$ \\
Completed $8^{\text {th }}$ grade and quit & $4(4.7)$ \\
High school incomplete & $2(2.3)$ \\
Completed high school & $6(7.0)$ \\
Paid work & $41(47.7)$ \\
Yes & $45(52.3)$ \\
No & \\
Number of husbands/partners in life & $70(81.4)$ \\
1 & $14(16.3)$ \\
2 & $2(2.3)$ \\
3 & $13(16.9)$ \\
Duration of marital relationship (years) & $18(23.4)$ \\
$1-5$ & $23(29.8)$ \\
$6-10$ & $9(11.7)$ \\
$11-15$ & $14(18.2)$ \\
$16-20$ & \\
21 or more & \\
\hline
\end{tabular}

*When one or more husband/partner were present, the last relationship was considered 
Table 2 - Prevalence of lifetime physical marital violence $(\mathrm{N}=86)$. Embu, Southeastern Brazil, 1999.

\begin{tabular}{lcc}
\hline Physical marital violence & $\mathrm{n}(\%)$ & Lifetime \\
\hline Type of physical aggression* & & $(95 \% \mathrm{Cl})$ \\
$\quad$ Slapping (open hand) & $28(32.6)$ & $(22.7-42.5)$ \\
$\quad$ Kicking & $10(10.6)$ & $(4.1-17.1)$ \\
$\quad$ Hitting with fist & $15(17.5)$ & $(9.5-25.5)$ \\
Beating & $13(15.2)$ & $(6.6-22.8)$ \\
Using/threatening to use weapon & $12(13.9)$ & $(2.3-13.9)$ \\
Other & $7(8.1)$ & $(32.7-34.7)$ \\
Any type of violence** & $29(33.7)$ & $(13.3-30.9)$ \\
Severe violence*** & $19(22.1)$ & $(4.0-17.0)$ \\
Non-severe violence*** & $9(10.5)$ & \\
*Multiple forms of aggression are possible & & \\
$* *$ Any of the types above & & \\
$* * *$ Kicking and/or hitting with fist and/or beating and/or using/threatening to use weapon & \\
$* * * *$ Slapping, in the absence of severe violence & &
\end{tabular}

clude a husband/partner (12.8\%), women indicated themselves as the head of the household.

Among behaviors defined as physical marital violence, slapping was the most frequent (32.6\%), followed by hitting with fist (17.5\%), beating (15.2\%), using/threatening to use weapon (13.9\%), and kicking $(10.6 \%)$, with the occurrence of multiple forms of physical aggression being possible (Table 2). In the "other types of violence" item, $8.1 \%$ of women spontaneously reported "hammering on the head," "shoving," "drumming," "striking the woman," "throwing an object on the head," "strangling, suffocating," or "hurting with scissor and plier."

Considering groups of aggressive behaviors, we found that $33.7 \%$ (95\% CI: 32.7-34.7) of women $(n=29)$ suffered some type of physical violence inflicted by their husband/partner, of which $65.5 \%$ were characterized as severe violence $(n=19)$. Severe violence (22.1\%; 95\% CI: 13.3-30.9) was more frequent than non-severe violence (only slapping) $(10.5 \% ; 95 \%$ CI: 4.0-17.0) (Table 2). All women who had suffered severe violence in life also reported slapping by husbands/partners.

Victims of severe violence sought various sources of help; however, help was most frequently sought from the victim's family (47.4\%), the partner's family $(36.8 \%)$, and from friends (31.6\%). Traditional healers (21.1\%) and religious leaders (10.5\%) were also sought. Among institutions, the police (36.8\%) was most frequently sought, followed by women's right organizations/shelters (10.5\%), health care facilities (5.3\%), and mental health outpatient facilities (5.3\%) (Table 3).

When violence was not severe, women sought help mainly from their own family $(55.6 \%)$ or from their partner's family $(11.1 \%)$, in addition to religious leaders $(11.1 \%)$. These women did not seek help from healthcare institutions, law enforcement agencies, or women's rights organizations/shelters (Table 3).

Many of the victims of severe violence (15.8\%) never sought help, from either persons or institutions. This proportion was $44.4 \%$ among victims of non-severe violence.

\section{DISCUSSION}

The present study is one of the first in Brazil to provide population-based data on violence against women. In spite of the lack of precision of these estimates due to small numbers, the study contributes with important information on marital violence in the studied community. Prevalence rates for lifetime

Table 3 - Search for help due to episode of lifetime physical marital violence. Embu, Southeastern Brazil, 1999.

\begin{tabular}{|c|c|c|c|}
\hline Sources of help & $\begin{array}{l}\text { Severe violence } \\
\qquad(\mathrm{n}=19)\end{array}$ & $\begin{array}{l}\text { Any type } \\
\left(n=29^{*}\right)\end{array}$ & $\begin{array}{c}\text { Non-severe** } \\
(n=9)\end{array}$ \\
\hline Woman's family & $9(47.4)$ & $14(48.3)$ & $5(55.6)$ \\
\hline Partner's family & $7(36.8)$ & $8(27.6)$ & $1(11.1)$ \\
\hline Police & $7(36.8)$ & $7(24.1)$ & $0(0.0)$ \\
\hline Friends & $6(31.6)$ & $6(20.7)$ & $0(0.0)$ \\
\hline Traditional healer & $4(21.1)$ & $4(13.8)$ & $0(0.0)$ \\
\hline Religious leader & $2(10.5)$ & $3(10.3)$ & $1(11.1)$ \\
\hline Women's rights organizations/ shelters & $2(10.5)$ & $2(6.9)$ & $0(0.0)$ \\
\hline Health care facilities & $1(5.3)$ & $1(3.4)$ & $0(0.0)$ \\
\hline Mental health outpatient facilities & $1(5.3)$ & $1(3.4)$ & $0(0.0)$ \\
\hline Community leader & $0(0.0)$ & $0(0.0)$ & $0(0.0)$ \\
\hline Others*** & $2(10.5)$ & $2(6.9)$ & $0(0.0)$ \\
\hline Never sought help & $3(15.8)$ & $8(27.6)$ & $4(44.4)$ \\
\hline
\end{tabular}

Never sought help

(15.8)

$4(44.4)$

*Includes one woman who reported only one type of physical aggression (strangling/suffocating)

**Slapping, in the absence of severe violence

***Municipal government social worker or neighbor 
marital violence may have been underestimated due to recall bias or to the fear of reporting marital violence, even though subjects were interviewed in private, by women, at the local health facility, which avoided the discomfort of discussing intimate subjects with a male interviewer and the risk of being overheard by the husband. In addition, our estimates show that marital violence is a relevant problem in a low-income population in the periphery of the São Paulo metropolitan area; these estimates may potentially be extended to other similar communities in the outskirts of large Brazilian cities.

Table 4 shows population-based studies of the life- time prevalence of physical marital violence, grouped according to the country or continent of origin. On the whole, the rates of physical marital violence found in the present study were higher than those found in developed countries and similar to or lower than those found in other developing countries.

There are similarities between the definitions of physical marital violence used in the present study and those used in the majority of studies conducted in developed countries. In spite of this, the greater frequency of physical marital violence in the Brazilian sample may be attributed to the lower socioeconomic level of the present community when com-

Table 4 - Prevalence of lifetime physical marital violence in different countries.

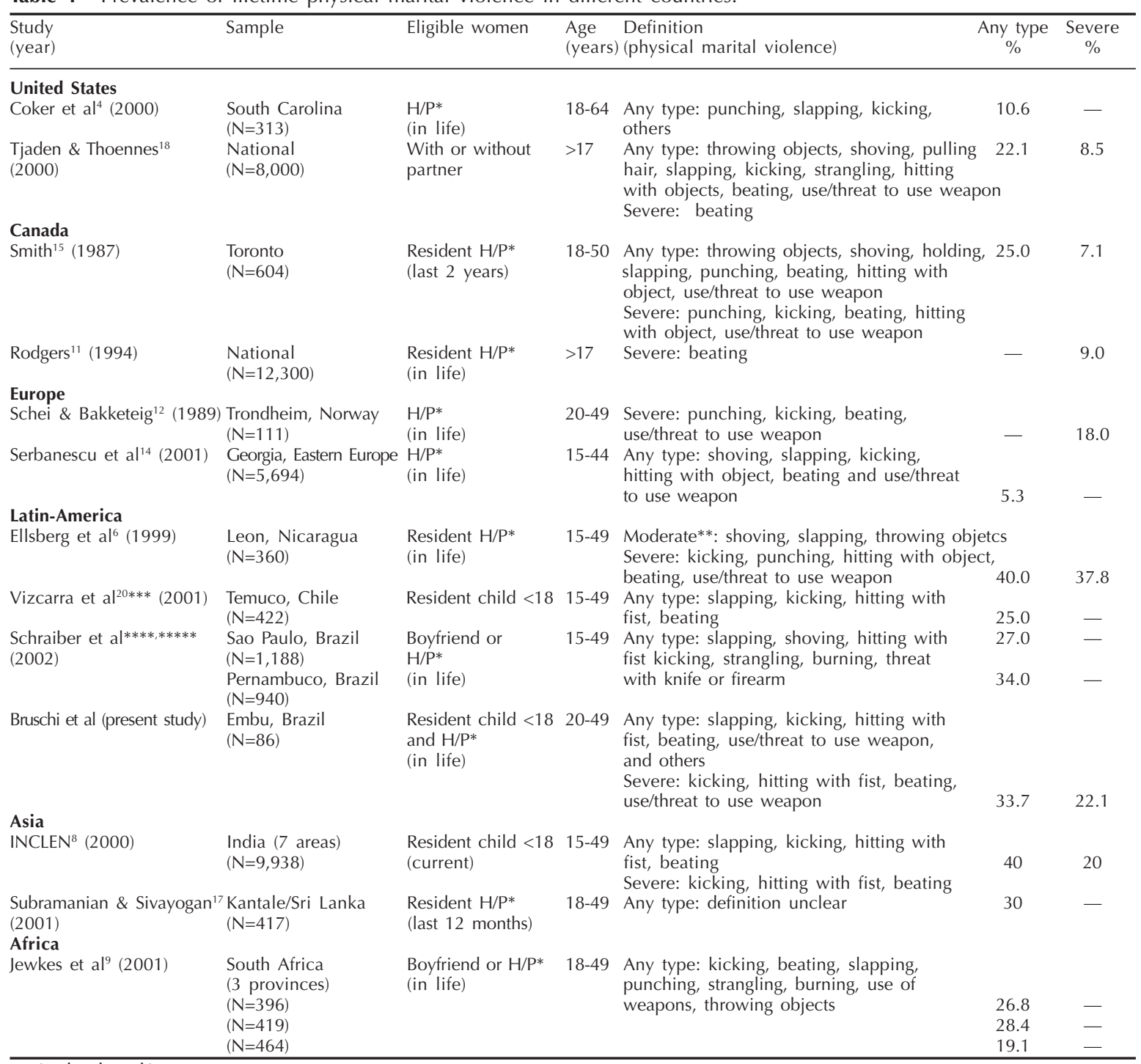

*H/P=husband/partner

**Moderate violence excludes severe violence

*** Losses not reported

****Schraiber LB, Oliveira AFPL, França-Jr I, Diniz CSG, Portella AP, Ludermir AB, et al. Violência contra a mulher e saúde no Brasil. São Paulo: Departamento de Medicina Preventiva da Faculdade de Medicina da Universidade de São Paulo; 2002. *****Schraiber LB, Oliveira AFPL, França-Jr I, Diniz CSG, Portella AP, Ludermir AB et al. Prevalência de violência física contra a mulher cometida por parceiros na cidade de São Paulo e Zona da Mata de Pernambuco e sua distribuição segundo características sociodemográficas [resumo]. Rev Bras Epidemiol. 2002;(Supl Esp):36 
pared to the populations evaluated by American, Canadian, and European surveys. Indeed, associations between low income and physical marital violence have been reported by several authors. ${ }^{4,6,8,17}$ Furthermore, rates from developed countries may have been underestimated by certain methodological characteristics of the studies, such as sample selection and data collection procedures. As the majority of these studies was based on random telephone dialing, one may suppose that households without telephone, which were excluded from the sample, are exactly those with lower income and at higher risk of physical marital violence. It is also possible that the use of telephone interviews may have hindered the disclosure of such a sensitive problem as marital violence, which would more easily be addressed by personal contact. The large number of refusals, reaching almost $50 \%$ in some studies, confirms this hypothesis and contributes to minimizing the registered prevalence rates.

As to the studies conducted in developing countries, ${ }^{6,8,9,17,20}$ not all of them reported lifetime physical marital violence rates (any type or severe) based on clear definitions. In Brazil, Schraiber et al* adopted a methodology very similar to that of the present study, finding prevalence rates of any type of lifetime physical marital violence of $27 \%$ in the Municipality of São Paulo and 34\% in the Zona da Mata, state of Pernambuco, in Northeastern Brazil. The rate of any type of physical violence found in the present study was closer to that reported for the Zona da Mata, probably due to the similarity between the population of women in the two regions. The Embu community is characterized by a large number of migrants from Northeastern Brazil, low income, and low schooling. When considering only the women in the same level of schooling from the São Paulo and Zona da Mata samples, there was no difference in terms of marital violence rates. ${ }^{*}$ This suggests that differences in prevalence may reflect differences in socioeconomic level between the samples much more than other differences between the sites studied. In Chile, ${ }^{20}$ WorldSAFE researchers found $25 \%$ prevalence of any type of physical marital violence, which was below that obtained in the present study, but was similar to that reported by Schraiber et al* in São Paulo. The similarity between the rates obtained by Vizcarra et $\mathrm{al}^{20}$ and Schraiber et al* may be related to similarities between the Chilean and São Paulo samples, both of which included lower and middle class women.

In Nicarágua, ${ }^{6}$ the prevalence of severe violence was greater than that observed in the present study, prob- ably due to the inclusion of "hitting with an object" into the definition of severe violence. In India, ${ }^{8}$ WorldSAFE researchers reported a prevalence of severe violence similar to that obtained in the present study, in spite of the cultural differences and of the inclusion of slums and rural areas into the Indian sample. In three South African provinces 9 (two urban and one rural), the prevalence of any type of violence was lower than the expected, and may have been underestimated due to the tendency of women to omit less severe aggression for considering it as part of the normal relationship with their partners (Table 4).

In the present survey, victims of physical marital violence sought help more often from persons than from institutions. This pattern was also observed in other studies, ${ }^{1,4,8,11,14, *}$ which suggests that women still consider marital violence as a problem to be dealt with within the private sphere.

In the studied sample, violence victims sought the help of members of their own families more often than that of friends, in proportions similar to those found in the Zona da Mata* (Table 5). This similarity is probably due to the large proportion of Northeastern migrants among the residents of Embu. According to Schraiber et al, ${ }^{*}$ the greater search for friends in the city of São Paulo reflects the greater freedom of São Paulo women to establish extra-family relationships when compared to those of the Zona da Mata. The rate of seeking help from friends in Mexico ${ }^{1}$ was among the lowest found in the studies identified, possibly due to sociocultural characteristics of that population, which include the fact that husbands often forbid their wives from working and having friends, thus restricting social contact.

In Embu, the partner's family was sought to a lesser extend than the victims own family, confirming the findings of Schraiber et al* and Alvarado-Zaldivar et al. ${ }^{1}$ Two other studies, one American ${ }^{4}$ and one Canadian, ${ }^{11}$ reported rates of seeking help from any family, combining in one variable both the victims' and the partners' families. Notwithstanding, both studies found high rates of seeking help from friends among victims of lifetime marital violence (Table 5). A lower rate was found in the studied sample, reflecting the cultural difference between the two populations, insofar as, in the United States and Canada, social relationships are more extra-familiar, whereas in Brazil they are more centered on the family.

Despite frequently being treated as a private issue, marital violence is reaching the public spheres, in-

*Schraiber LB, Oliveira AFPL, França-Jr I, Diniz CSG, Portella AP, Ludermir AB, et al. Violência contra a mulher e saúde no Brasil. São Paulo: Departamento de Medicina Preventiva da Faculdade de Medicina da Universidade de São Paulo; 2002. 
Table 5 - Persons and institutions sought by victims of lifetime physical marital violence (any type and severe).

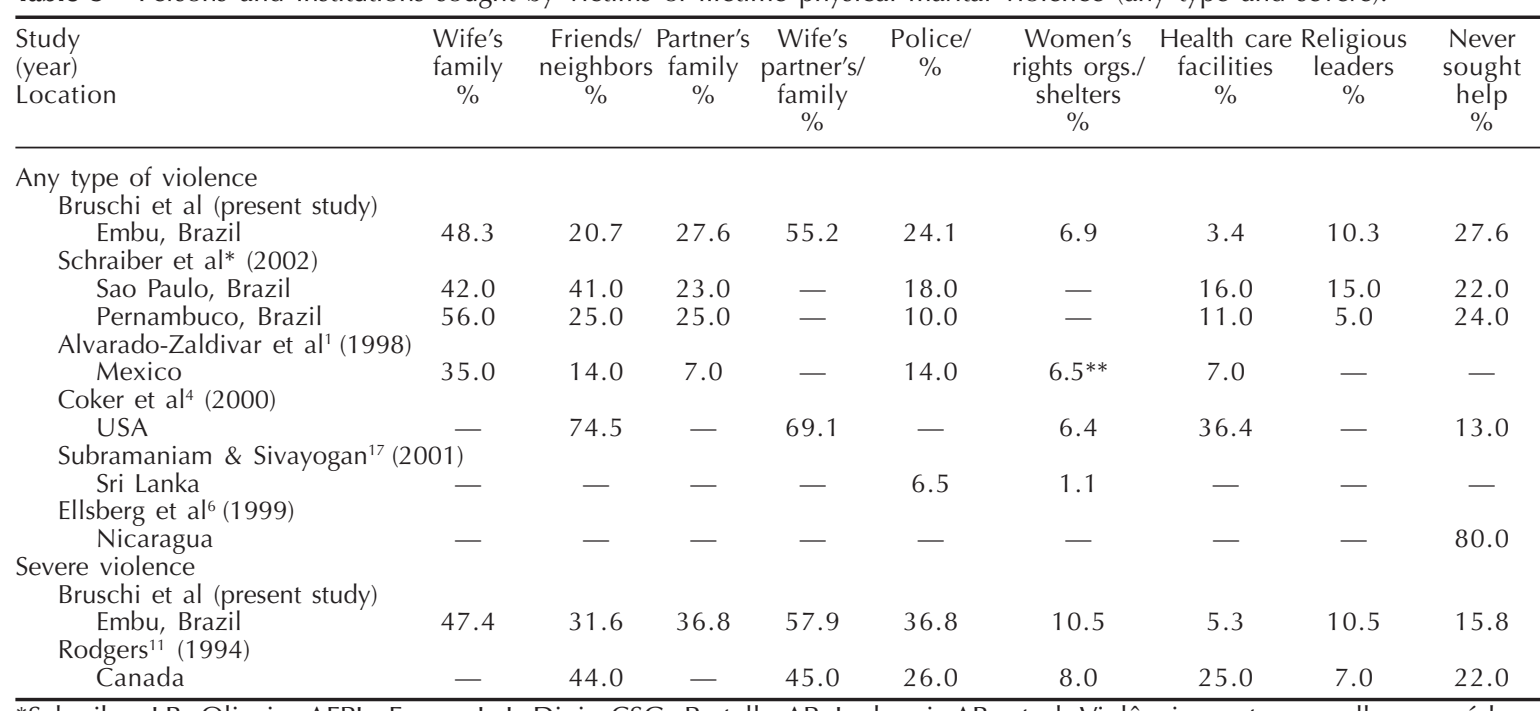

*Schraiber LB, Oliveira AFPL, França-Jr I, Diniz CSG, Portella AP, Ludermir AB, et al. Violência contra a mulher e saúde no Brasil. São Paulo: Departamento de Medicina Preventiva da Faculdade de Medicina da Universidade de São Paulo; 2002.

**National System for the Integral Development of the Family

cluding police departments, healthcare services, and women's rights organizations. Of the institutions most frequently mentioned as sources of help by the women in the present study, the police and women's rights organizations/shelters are worthy of note. Regarding the seeking of help from the police in cases of physical marital violence (any type or severe), the rate found in Embu is greater than those reported in the remaining studies (Table 5). In the Brazilian sample, as in the Mexican ${ }^{1}$ one, the seeking of help from institutions was centered on the police, rather than on healthcare facilities. This was not observed in other studies, where there was a homogeneous distribution between the two types of institution. One may hypothesize that the studied community may not consider domestic violence as a health matter, but rather as a police issue. This is supported by the fact that Embu has a high rate of urban violence, with higher homicide rates and number of police occurrences than those found in the city of São Paulo.* Moreover, few women talk about marital violence with healthcare professionals, who also do not usually ask about these issues during appointments. ${ }^{13}$ The greater search for the police in the studied neighborhood may also have been favored by the presence, in that region, of a woman's police station. In Brazil, police stations specializing in violence against women, composed solely of female officers, play a fundamental role in fighting domestic violence. ${ }^{7}$

In the present study, the rate of seeking help from women's rights organizations/shelters were close to those registered in other countries, despite the differences between the populational groups surveyed. The similarity with the Mexican ${ }^{1}$ and American ${ }^{4}$ rates with respect to any type of lifetime violence and with the Canadian ${ }^{11}$ rate of lifetime severe violence may indicate that Brazil is not as far from developed countries in terms of the availability of this kind of institution.

In Embu, $13.8 \%$ of the victims of any type of physical marital violence sought help from traditional healers, and $10.3 \%$ resorted to religious leaders. In the study by Schraiber et al, ${ }^{* *}$ the seeking of help from religious leaders was greater in São Paulo (15\%) than in the Zona da Mata (5\%). The strong African influence on the religiosity of the Brazilian population, especially in the Northeast, suggests that victims in the Zona da Mata may be seeking help from a source not mentioned in that study. Health care facilities, available in the area, were less sought than the police and traditional healers in cases of severe violence. This emphasizes the importance of investigating the cultural aspects involved in fighting domestic violence in Brazil.

In the studied neighborhood, many victims of physical marital violence never sought help from either persons or institutions. The frequency of this condition among women who suffered any type of physical marital violence in Embu was similar to that found by Schraiber et al** in the city of São Paulo and in the Zona da Mata, higher than that observed in the United States, ${ }^{4}$ and much lower than that found in

*Fundação Sistema Estadual de Análise de Dados - SEADE. Informações dos municípios paulistas. Available online at: http:// www.seade.gov.br/produtos/imp/ [2005 Sep 16].

**Schraiber LB, Oliveira AFPL, França-Jr I, Diniz CSG, Portella AP, Ludermir AB, et al. Violência contra a mulher e saúde no Brasil. São Paulo: Departamento de Medicina Preventiva da Faculdade de Medicina da Universidade de São Paulo; 2002. 
Nicaragua $^{6}$ (Table 5). Regarding severe violence, a greater proportion of Canadian victims did not seek help when compared to victims from Embu. The fact that, in Nicaragua, over $41 \%$ of victims reported being threatened by their partners with further beating or death, for themselves or their children, in case they mentioned the violence to others, suggests that fear may be an important reason for not seeking help in other countries as well.

\section{REFERENCES}

1. Alvarado-Zaldivar G, Salvador-Moysén J, EstradaMartínez S, Terrones-Gonzáliz A. Prevalência de violencia doméstica en la ciudad de Durango. Salud Pública Méx. 1998;40(6):481-6.

2. Azevedo MA, Paternostro ME, Vaiciunas N, Guerra VNA. Mulheres espancadas: a violência denunciada. São Paulo: Cortez; 1995.

3. Bangdiwala SI, Paula CS, Ramiro LS, Muñoz SR. Coordination of international multi-center studies: governance and administrative structure. Salud Pública Méx. 2003;45(1):58-66.

4. Coker AL, Derrick C, Lumpkin JL, Aldrich TE, Oldendick R. Help-seeking for intimate partner violence and forced sex in South Carolina. Am J Prev Med. 2000;19(4):316-20.

5. Deslandes SF, Gomes R, Silva CMFP. Caracterização dos casos de violência doméstica contra a mulher atendidos em dois hospitais públicos do Rio de Janeiro. Cad Saúde Pública. 2000;16(1):129-37.

6. Ellsberg MC, Pena R, Herrera A, Liljestrand J, Winkvist A. Wife abuse among women of childbearing age in Nicarágua. Am J Public Health. 1999;89(2):241-4.

7. Human Rights Watch - HRW. Injustiça criminal: violência contra a mulher no Brasil. Washington (DC); 1992

8. International Clinical Epidemiology Network - INCLEN. Worldsafe and Indiasafe: studying the prevalence of family violence. Philadelphia (PA); 2000. (Monograph Series on Critical International Health Issues, 9).

9. Jewkes R, Penn-Kekana L, Levin J, Ratsaka M, Schrieber M. Prevalence of emotional, physical and sexual abuse of women in three south african provinces. S Afr Med J. 2001;91(5):421-8.

10. Krug EG, Dahlberg LL, Mercy JA, Zwi AB, Lozano R, editors. World report on violence and health. Geneva: WHO; 2002. Violence by intimate partners; p. 87-121.
In conclusion, lifetime physical marital violence is frequent in the studied community. Violence is dealt with within the private realm, and some victims do not seek help at all. Health care professionals were not acknowledged by the community as potential sources of help or counseling in cases of marital violence. Campaigns for increasing awareness and clarifying the role of healthcare facilities may facilitate revert this scenario by emphasizing their role as an option for help.

11. Rodgers K. Wife assault: the findings of a national survey. Ottawa: Statistics Canada; 1994.

12. Schei D, Bakketeig LS. Gynaecological impact of sexual and physical abuse by spouse: a study of a random sample of norwegian women. Br J Obstet Gynaecol. 1989;96(2):1379-83.

13. Schraiber LB, d'Oliveira AFPL, França Júnior I, Strake SS, Oliveira EA. A violência contra mulheres: demandas espontâneas e busca ativa em unidade básica de saúde. Saúde Soc. 2000;9(1-2):3-15.

14. Serbanescu F, Morris L, Stratila M, Bivol O. Reproductive health survey, Moldova, 1997. Atlanta (GA): Center for Disease Control, US Department of Health and Human Services; 1998.

15. Smith MD. The incidence and prevalence of woman abuse in Toronto. Violence Vict. 1987;2(3):173-87.

16. Straus MA. Measuring intrafamiliar conflict and violence: the conflict tactics (CT) scales. J Marriage Fam. 1979;41(1):75-88.

17. Subramaniam $\mathrm{P}$, Sivayogan $\mathrm{S}$. The prevalence and pattern of wife beating in the Trincomalee district in eastern Sri Lanka. Southeast Asian J Trop Med Public Health. 2001;32(1):186-95.

18. Tjaden P, Thoennes N. Full report of the prevalence, incidence, and consequences of violence against women: findings from the national violence against women survey. Washington (DC): U.S. Department of Justice. Office of Justice Programs; 2000.

19. Venturi G, Recaman M, Oliveira S, organizadores. A mulher brasileira nos espaços público e privado. São Paulo: Fundação Perseu Abramo; 2004.

20. Vizcarra MB, Cortés J, Bustos L, Alarcón M, Muñoz S. Violencia conyugal en la ciudad de Temuco: un estudio de prevalencia y factores asociados. Rev Méd Chile. 2001;129(12):1405-12.

Supported by the International Clinical Epidemiology Network (INCLEN - Process no. 1004-98-5213-RC\#61) and by the Fundo de Auxílio aos Docentes e Alunos (FADA) of the Escola Paulista de Medicina, Universidade Federal de São Paulo.

Based on the Master's dissertation presented at the Escola Paulista de Medicina, Universidade Federal de São Paulo in 2003. 